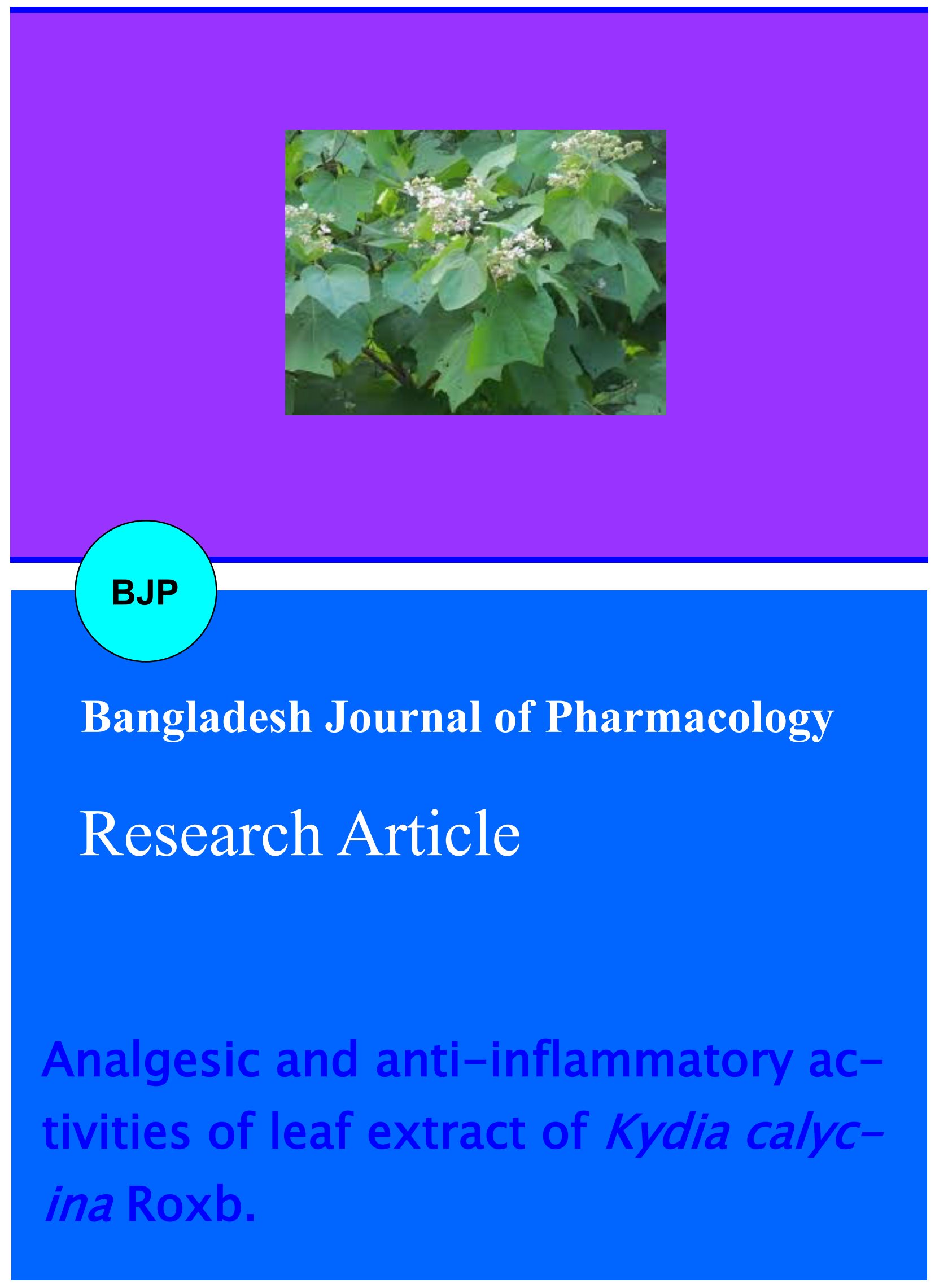


Abstracted/indexed in Academic Search Complete, Agroforestry Abstracts, Asia Journals Online, Bangladesh Journals Online, Biological Abstracts, BIOSIS Previews, CAB Abstracts, Current Abstracts, Directory of Open Access Journals, EMBASE/Excerpta Medica, Google Scholar, HINARI (WHO), International Pharmaceutical Abstracts, Open J-gate, Science Citation Index Expanded and Social Sciences Citation Index

ISSN: $1991-0088$

\title{
Analgesic and anti-inflammatory activities of leaf extract of Kydia calycina Roxb.
}

\author{
Baburao Bhukya', Rama Narsimha Reddy Anreddy ${ }^{2}$, Carey M. William¹ and Krishna Mo- \\ han Gottumukkala'
}

${ }^{1}$ Department of Pharmacognosy and Ethnopharmacology; ${ }^{2}$ Department of Pharmacology, University College of Pharmaceutical Sciences, Kakatiya University, Warangal 506009, India.

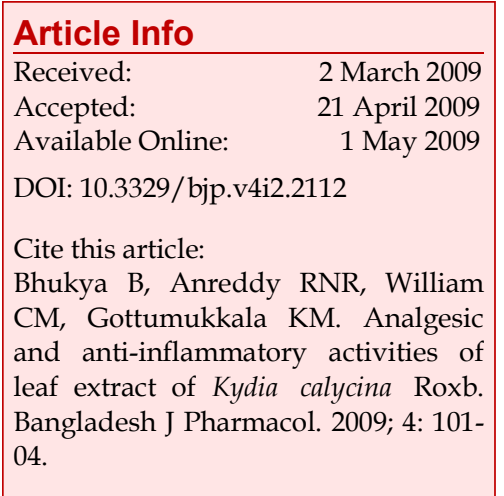

\begin{abstract}
The methanol extract of leaves of Kydia calycina Roxb. was screened for the analgesic (using hot plate test and acetic acid-induced writhing test in mice) and anti-inflammatory (using rat paw edema test) activity at the doses of 200 and $400 \mathrm{mg} / \mathrm{kg}$ body weight. A significant $(\mathrm{p}<0.0005)$ analgesic effect was observed with 200 and $400 \mathrm{mg} / \mathrm{kg}$ in both tests. The maximum antiinflammatory response was produced at 3 hours with extract doses of 200 and $400 \mathrm{mg} / \mathrm{kg}$. These results suggest that the methanol extract of $K$. calycina has exhibited significant analgesic and anti-inflammatory effects, which were comparable with standard drugs.
\end{abstract}

\section{Introduction}

Kydia calycina Roxb. (synonym: Kydia fraternal) is a herb of the family Malvaceae which is distributed in tropical Himalayas from the Indus eastwards to Myanmar (Burma) and in peninsular India from northern Maharastra and Madhya Pradesh south-wards, chiefly in mixed, moist, deciduous forests (Parrotta, 2001). The leaves of $K$. calycina were 7.5-15 cm long and wide, usually 3-7 lobed, apex angled or rounded, base cordate, palmately 7-nerved, hoary-tomentose beneath; petioles $2.5-5 \mathrm{~cm}$. Among the Santalis, a paste of the pounded leaves is applied to relieve body pains, arthritis and lumbago; a poultice of the leaves is reportedly used to treat skin diseases (Parrotta, 2001). So far no information is available for the analgesic and anti inflammatory activity of the methanol extract of $K$. calycina. So, the present study has been undertaken to evaluate the analgesic and anti inflammatory activity of the methanol extract of $K$. calycina using hot plate, writhing and rat paw edema methods.

\section{Materials and Methods}

\section{Plant material}

The leaves of K. calycina were collected from Thirupathi hills, Andhara Pradesh, India. It was authenticated by Prof. V. Raju, Department of Botany, Kakatiya University, Warangal, India.

\section{Preparation of extract}

The leaves were cut into small pieces and shed dry and then ground into coarse powder for the maceration process with methanol at room temperature. After exhaustive extraction, the methanol extract was concentrated under reduced pressure at $50-55^{\circ} \mathrm{C}$ and 
stored in a vaccum desiccator. The suspension of the extract prepared in $2 \%$ gum acacia was used in the entire experimental studies.

\section{Drugs and chemicals}

The drugs and chemicals used were carrageenan and acetic acid (SD fine chemicals Limited, Mumbai), gum acacia and diclofenac sodium (Dr. Reddy's Labs, Hyderabad), Pentazocine (Pure Pharma Ltd., Mumbai) and methanol (Merck, Mumbai).

\section{Phytochemical screening}

The methanol extract was screened for the presence of various phytoconstituents like steroids, alkaloids, terpenoids, glycosides, flavonoids, phenolic compounds and carbohydrates (Trease and Evan, 1983).

\section{Animals}

Wister rats (175-250 g) and albino mice (25-30 g) of either sex were selected and maintained under standard husbandry conditions and had free access to food and water ad libitum. The animals were allowed to acclimatize to the environment for 7 days prior to the experimental session. The animals were divided into different groups each consist of six animals were fasted overnight prior to the experiments. Experiments on animals were performed in accordance with guidelines of the Institutional Animal Ethical Committee.

\section{Hot-plate test}

The hot plate test was used to measure analgesic activity by the method described by Eddy and Leimback (1953) with minor modifications. In this experiment, the hot plate was maintained at $55 \pm 0.5^{\circ} \mathrm{C}$. All animals were selected 24 hour prior to experimentation and the animals were selected on the basis of their normal reaction time i.e., pain response to the hot plate to the minimum and maximum of 2-15 sec respectively. In order to avoid the damage to the paws of the animals, the time standing on the plate was limited to $20 \mathrm{sec}$. Pentazocine $10 \mathrm{mg} / \mathrm{kg}$ was administered intraperitoneally as a reference standard. $30 \mathrm{~min}$ after administration of vehicle ( $2 \%$ gum acacia)/methanol extract (200 and $400 \mathrm{mg} / \mathrm{kg}$ )/standard drug, animals were placed individually on to the hot plate and the time from placing the animal on the hot plate to jumping of the animal from the hot plate was recorded as the reaction time or latency of the pain response.

\section{Writhing test}

Abdominal construction induced by intraperitoneal injection of acetic acid was carried out according to the procedures described previously (Koster et al., 1959).
The leaf extract of K. calycina was tested at 200 and 400 $\mathrm{mg} / \mathrm{kg}$. Diclofenac sodium, a reference antiinflammatory and analgesic compound, was used at 20 $\mathrm{mg} / \mathrm{kg}$. The extract and reference drug were administered orally 30 min before the administration of $0.7 \%$ acetic acid in a volume of $10 \mathrm{mg} / \mathrm{kg}$ i.p. Control animals received $2 \%$ of gum acacia under the same experimental condition. Immediately after injection of the acetic acid, each animal was isolated in an individual cage and the normal construction was cumulatively counted for a period of $20 \mathrm{~min}$, beginning 3 min after acetic acid injection. The number of writhing and stretching was recorded and the \% was calculated using the following ratio: \% of protection= (Control mean-Treated mean)/Control mean $\times 100$

Screening for anti-inflammatory activity by rat paw edema method

The normal paw volumes of all the rats were measured initially and were divided into four groups each consists of six animals treated orally with the vehicle as control ( $2 \%$ gum acacia), standard diclofenac sodium $(20 \mathrm{mg} / \mathrm{kg}$ ) and methanol extract (200 and $400 \mathrm{mg} / \mathrm{kg}$ ) respectively. Carrageenan $(0.1 \mathrm{~mL}$ of a $1 \%$ suspension in saline) was injected sub plantar region of the right hind paw of each rat. The vehicle, drug and extract were administered $30 \mathrm{~min}$ prior to the injection of Carrageenan. The paw volumes of all the rats were recorded at 1, 2, 3 and 4 hours after Carrageenan treatment by using plethysmometer (Winter et al., 1962). A significant reduction in the paw volume compared to vehicle treated control animals was considered as inflammatory response.

\%Inhibition $=\left[\left(\mathrm{V}_{\mathrm{T}}-\mathrm{V}_{0}\right)\right.$ control $-\left(\mathrm{V}_{\mathrm{T}}-\mathrm{V}_{0}\right)$ treated groups] / $\left(\mathrm{V}_{\mathrm{T}}-\mathrm{V}_{0}\right)$ control *100

$\mathrm{V}_{0}=$ paw volume of the rat before administration of Carrageenan

$\mathrm{V}_{\mathrm{T}}=$ paw volume of the rat after administration of Carrageenan at different time intervals

\section{Statistical analysis}

All the results were expressed as Mean \pm Standard deviation (SD). Data was analyzed using one-way ANOVA followed by Dunnett's t-test. P values $<0.05$ were considered as statistically significant.

\section{Results and Discussion}

Preliminary phytochemical screening of the methanolic extract of K. calycina reveals the presence of steroids, terpenoids, carbohydrates and glycosides. 


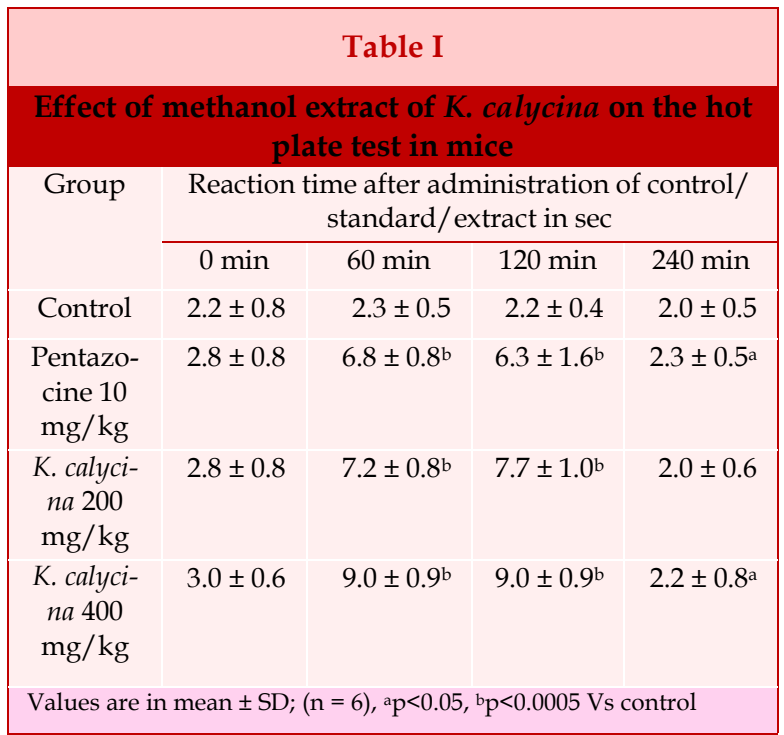

\begin{tabular}{|c|c|c|}
\hline \multicolumn{3}{|c|}{ Table II } \\
\hline \multicolumn{3}{|c|}{$\begin{array}{l}\text { Effect of methanol extract from } K \text {. calycina on ace- } \\
\text { tic acid-induced writhing test in mice }\end{array}$} \\
\hline Group & $\begin{array}{l}\text { Number } \\
\text { of writhes }\end{array}$ & $\%$ Inhibition \\
\hline Control & $79.5 \pm 6.0$ & - \\
\hline Diclofenac sodium $20 \mathrm{mg} / \mathrm{kg}$ & $17.2 \pm 3.5^{\mathrm{a}}$ & $78.5 \pm 3.6$ \\
\hline K. calycina $200 \mathrm{mg} / \mathrm{kg}$ & $40.8 \pm 4.0^{a}$ & $48.1 \pm 8.7$ \\
\hline K. calycina $400 \mathrm{mg} / \mathrm{kg}$ & $32.5 \pm 2.8^{a}$ & $58.8 \pm 6.3$ \\
\hline \multicolumn{3}{|c|}{ Values are in mean $\pm S D ;(n=6)$; ${ }^{p}<0.00001$ vs control } \\
\hline
\end{tabular}

In this study, we have demonstrated the effect of extract $(200$ and $400 \mathrm{mg} / \mathrm{kg}$; p.o.) on hot plate test and acetic acid induced writhing in mice. The results of hot plate test and acetic acid induced writhing test were shown in Table I and II. The extract (200 and $400 \mathrm{mg}$ / $\mathrm{kg}$ ) showed the significant increase in reaction time and reduction in the number of writhes induced by acetic acid in a dose-dependent manner which were comparable with reference compounds, diclofenac and pentazocine respectively. A significant $(p<0.0005)$ analgesic effect to the thermal stimulus was observed at $60 \mathrm{~min}$ with 200 and $400 \mathrm{mg} / \mathrm{kg}$ of K. calycina which is comparable to the effect of standard pentazocine. The mouse writhing assay is useful test to evaluate mild analgesic agents. This method is not only simple and reliable but also affords rapid evaluation of peripheral type of analgesic action. In this test the animals react with characteristic stretching behavior, which is called writhing. Acetic acid causes algesia by liberating endogenous substances including serotonin, histamine, PGs, bradykinin and substance $P$ which stimulate pain nerve endings (Ochi et al., 2000). Local peritoneal

\begin{tabular}{|c|c|c|c|c|}
\hline \multicolumn{5}{|c|}{ Table III } \\
\hline \multicolumn{5}{|c|}{$\begin{array}{l}\text { Effect of methanol extract from } K \text {. calycina on the } \\
\text { paw edema test in rats }\end{array}$} \\
\hline Group & 1 hour & 2 hours & 3 hours & 4 hours \\
\hline Control & $0.2 \pm$ & $0.2 \pm$ & $0.2 \pm$ & $0.2 \pm$ \\
\hline & 0.02 & 0.03 & 0.03 & 0.02 \\
\hline Diclofenac & $0.1 \pm$ & $0.1 \pm$ & $0.1 \pm$ & $0.1 \pm$ \\
\hline $\begin{array}{l}\text { sodium } 20 \\
\mathrm{mg} / \mathrm{kg}\end{array}$ & $0.01^{\mathrm{a}}$ & $0.02^{\mathrm{b}}$ & $0.02^{c}$ & $0.01^{\circ}$ \\
\hline K. calycina & $0.2 \pm$ & $0.1 \pm$ & $0.1 \pm$ & $0.1 \pm$ \\
\hline $200 \mathrm{mg} / \mathrm{kg}$ & $0.02^{a}$ & $0.02^{\mathrm{b}}$ & $0.01^{\mathrm{c}}$ & $0.01^{\mathrm{c}}$ \\
\hline K. calycina & $0.2 \pm$ & $0.1 \pm$ & $0.1 \pm$ & $0.1 \pm$ \\
\hline $400 \mathrm{mg} / \mathrm{kg}$ & $0.01^{\mathrm{a}}$ & $0.02^{\mathrm{b}}$ & $0.01^{\mathrm{c}}$ & $0.02 \mathrm{c}$ \\
\hline
\end{tabular}

receptors are postulated to be partly involved in the abdominal constriction (writhing) response.

The method has been associated with prostanoids in general, i.e. increases levels of $\mathrm{PGE}_{2}$ and $\mathrm{PGF}_{2 \alpha}$ in peritoneal fluids as well as lipoxygenase products (Ochi et al., 2000). It was found that extract significantly inhibited the acetic acid induced writhing response. The abdominal constriction is related to the sensitization of nociceptive receptors to prostaglandins. It is therefore possible that extract produced analgesic effect may be probably due to the inhibition of synthesis or action of prostaglandin.

Carrageenan-induced rat paw edema is a suitable test for evaluating anti-inflammatory drugs which has frequently been used to assess the anti-edematous effect of natural products (Panthong et al., 2003). Development of edema in the paw of the rat after injection of carrageenan is a biphasic event. The initial phase observed during the first hour is attributed to the release of histamine and serotonin. The second phase of edema is due to the release of prostaglandins, protease and lysosome (Vinegar et al., 1969; Crunkhon and Meacock, 1971). Based on this, it could be argued that the suppression of the first phase may be due to inhibition of the release of early mediators, such as histamine and serotonin, and the action in the second phase may be explained by an inhibition of cyclooxygenase. Sub plantar injection of carrageenan in rats showed to a time-dependent increase in paw thickness (Table III); this increase was observed at 1 hour and was maximal at 3 hours after administration of carrageenan injection in the vehicle treated groups. The results of MEKC against Carrageenan induced paw edema is shown in Table III. There was a dosedependent inhibitory activity in Carrageenan induced paw inflammation at all assessment times. Diclofenac 
sodium, a COX-inhibitor at the dose of $20 \mathrm{mg} / \mathrm{kg}$, p.o. significantly reduced the paw edema. This indicates action against release of histamine, serotonin and kinins in early phase, while later phases are suspected to be arachidinate metabolites producing an edema-dependent on mobilization of neutrophils (Just et al., 1998). The result of the present study indicates that PG (200 and $400 \mathrm{mg} / \mathrm{kg}$, p.o.) and indomethacin play a crucial role as protective factors against the carrageenaninduced acute inflammation.

\section{Conclusion}

This study demonstrated that the methanol extract of $K$. calycina have a significant analgesic and anti inflammatory activity.

\section{Acknowledgements}

The authors wish to thank Principal, UCPSc, Kakatiya University, Warangal for providing the research facilities. The first author also wishes to thank University Grants Commission (UGC), India for providing Junior Research Fellowship.

\section{References}

Crunkhon P, Meacock SER. Mediators of the inflammation induced in the rat paw by carrageenan. Bri J Pharmacol.
1971; 42: 392-402.

Eddy NB, Leimback D. Synthetic analgesic. II. Dithienylbutenyl and dithienylbutylamines. J Pharmacol Exp Ther. 1953; 107: 385-93.

Just MJ, Recio MC, Giner RM, Cullar MJ, Manez S, Bilia AR. Anti-inflammatory activity of unusual lupine saponins from Bupleurum fruticescens. Planta Medica. 1998; 64: 404-07.

Koster R, Anderson M, De-Beer EJ. Acetic acid analgesic screen. Federation Proc. 1959; 18: 418-20.

Ochi T, Motoyama Y, Goto T. The analgesic effect profile of FR122047, a selective cyclooxygenase-1 inhibitor, in chemical nociceptive models. Eur J Pharmacol. 2000; 391: 49-54.

Panthong A, Kanjanapothi D, Taesotikul T, Wongcome T, Reutrakul V. Anti-inflammatory and antipyretic properties of Clerodendrum petasites S. Moore. J Ethnopharmacol. 2003; 85: 151-56.

Parrotta JA. Healing plants of peninsular India. New Delhi, CABI Publishing, 2001, pp 480-81.

Trease EG, Evan WC. Textbook of pharmacognosy. 12th ed, Oxford, Alden Press, 1983, pp 343-83.

Vinegar R, Schreiber W, Hugo R. Biphasic development of carrageenan edema in rats. J Pharmacol Exp Ther. 1969; 166: 96-103.

Winter CA, Risley EA, Nuss GW. Carrageenan-induced edema in hind paw of the rat as an assay for anti-inflammatory drugs. Proc Soc Exp Biol Med. 1962; 111: 544-47. 